\title{
Estrogen and n-3 polyunsaturated fatty acid supplementation have a synergistic hypotriglyceridemic effect in ovariectomized rats
}

\author{
Suhyun $\operatorname{Kim}^{1} \cdot$ Youri Jin ${ }^{1} \cdot$ Yongsoon Park $^{1}$ (D)
}

Received: 29 April 2015/ Accepted: 10 June 2015/Published online: 25 June 2015

(C) Springer-Verlag Berlin Heidelberg 2015

\begin{abstract}
The n-3 polyunsaturated fatty acids (PUFAs), EPA and DHA, as well as estrogen have been shown to decrease circulating levels of triglyceride (TG), but their underlying mode of action is unclear. The purpose of this study was to determine the effects of n-3 PUFA consumption and estrogen injection on TG metabolism. Rats $(n=48)$ were fed a modified AIN-93G diet with 0,1 , or $2 \% \mathrm{EPA}+\mathrm{DHA}$ relative to the total energy intake during 12 weeks. At 8 weeks, rats were ovariectomized (OVX), and after a 1-week recovery, rats were injected with either $17 \beta$-estradiol-3-benzoate $\left(E_{2}\right)$ or corn oil for the last 3 weeks. The n-3 PUFA consumption and $E_{2}$ injection independently decreased the hepatic expressions of sterol regulatory element-binding protein 1, acetyl-CoA carboxylase 1, fatty acid synthase (FAS), and diacylglycerol acyltransferase 2 (DGAT2) $(P<0.05)$. There were interactions between n-3 PUFA consumption and $E_{2}$ injection on hepatic expression of FAS and DGAT2. In addition, n-3 PUFA consumption and $\mathrm{E}_{2}$ injection upregulated the expression of AMP-activated protein kinase (AMPK), phosphorylated AMPK, peroxisomal proliferator-activated receptor $\alpha$, and carnitine palmitoyltransferase 1 in liver and skeletal muscle. $E_{2}$ injection increased the expression of estrogen receptor $\alpha$ and $\beta$ in skeletal muscle and liver, but n-3 PUFA consumption increased the expression of both receptors only in skeletal muscle. The present study suggests that the hypotriglyceridemic effects of $n-3$ PUFA consumption and $E_{2}$ injection could be due
\end{abstract}

Yongsoon Park

yongsoon@ hanyang.ac.kr

1 Department of Food and Nutrition, Hanyang University, Wangsimni-ro 222, Seongdong-gu, Seoul 133-791, South Korea to the down-regulation of hepatic TG synthesis and upregulation of TG oxidation in liver and skeletal muscle in OVX rats.

Keywords n-3 polyunsaturated fatty acids - Estrogen · Triglyceride $\cdot$ Ovariectomized rats

\section{Introduction}

Hypertriglyceridemia is a risk factor for clinical disorders including cardiovascular disease, stroke, type 2 diabetes mellitus, and metabolic syndrome (Bayturan et al. 2010). Studies have shown that lifestyle modification such as weight reduction, lower intake of saturated fatty acids, and higher intake of fish oil can decrease blood triglyceride (TG) concentration (Chapman et al. 2011; Jimenez-Gomez et al. 2010). In particular, a meta-analysis of clinical trials suggested that supplementation of $\mathrm{n}-3$ polyunsaturated fatty acids (PUFAs) eicosapentaenoic acid (EPA; 20:5, n-3) and docosahexaenoic acid (DHA; 22:6, n-3), which are rich in fish oil, reduces blood TG levels (Eslick et al. 2009).

It has been suggested that hypotriglyceridemic mechanisms of n-3 PUFAs could be due to the reduction in TG synthesis and the increase in TG clearance. In several studies, n-3 PUFA supplementation suppressed the synthesis of fatty acids and TG by reducing hepatic expression of the sterol regulatory element-binding protein 1 (SREBP1), acetyl-CoA carboxylase 1 (ACC1), fatty acid synthase (FAS), and diacylglycerol acyltransferase 2 (DGAT2) (Lu et al. 2011; Sekiya et al. 2003; Harris and Bulchandani 2006). Additionally, n-3 PUFA supplementation accelerated $\beta$-oxidation by increasing expression of peroxisome proliferator-activated receptor (PPAR) $\alpha$, 
carnitine palmitoyltransferase 1 (CPT1), and adenosine monophosphate-activated protein kinase (AMPK) in liver and/or skeletal muscle (Gonzalez-Manan et al. 2012; Hardie et al. 2012; Suchankova et al. 2005).

Similar to n-3 PUFA supplementation, estrogen treatment has been reported to have a hypotriglyceridemic effect. Previous studies showed that an ovariectomy procedure in rats caused hypertriglyceridemia (Hassan et al. 2013) and, in a human study, circulating TG concentrations were higher in postmenopausal than pre-menopausal women (Furusyo et al. 2013). Additionally, an estrogen injection prevented TG accumulation in liver and muscle of ovariectomized (OVX) mice by reducing fatty acid synthesis, increasing $\beta$-oxidation by down-regulating ACC1 and FAS, and up-regulating AMPK (D'Eon et al. 2005; Gorres et al. 2011). However, the effects of $E_{2}$ are unknown in regard to hepatic TG synthesis.

Stark and Holub (2004) reported that supplementation with n-3 PUFA had a hypotriglyceridemic effect in postmenopausal women who were receiving hormone replacement therapy. This result suggests an interaction between n-3 PUFA and estrogen. However, there are no studies elucidating underlying mechanisms of the interactions between n-3 PUFA supplementation and estrogen injection in relation to TG reduction. The purpose of this present study was to determine the interactions between n-3 PUFA supplementation and estrogen injection on TG synthesis and breakdown in OVX rats and, furthermore, the mechanism of this synergistic relationship.

\section{Materials and methods}

\section{Animal and experimental design}

The experimental protocol was approved by the Institutional Animal Care and Use Committee of Hanyang University (HY-IACUC-12-076). Three-week-old female Wistar rats (Jung Ang Lab Animal Inc., Seoul, Korea) were housed individually in ventilated cages in an air-conditioned room maintained at $22 \pm 1{ }^{\circ} \mathrm{C}$ with a relative humidity of $47 \pm 1 \%$ and 12-h light-dark cycle.

After 1 week of acclimation, 48 rats were randomly assigned to one of three isoenergetic modified American Institute of Nutrition (AIN)-93G diets with 0 , 1 , or $2 \%$ $\mathrm{EPA}+$ DHA for 12 weeks $(n=16$ per diet). AIN-93 G diet was made with fish oil containing EPA + DHA (3:2 ratio) and grape seed oil instead of soybean oil which contained 18:3n-3. Diets contained t-butylhydroquinone as an antioxidants and were sterilized by radiation. Table 1 shows the composition of the diet and fatty acids. The diet was provided as food pellets with fresh tap water ad libitum.
Table 1 Composition of the experimental diets

\begin{tabular}{|c|c|c|c|}
\hline Ingredient & $0 \% \mathrm{n}-3$ & $1 \% \mathrm{n}-3$ & $2 \% \mathrm{n}-3$ \\
\hline Corn starch (g/kg) & 424.55 & 424.60 & 424.60 \\
\hline Dextrose $(\mathrm{g} / \mathrm{kg})$ & 132.00 & 132.00 & 132.00 \\
\hline Sucrose $(\mathrm{g} / \mathrm{kg})$ & 100.00 & 100.00 & 100.00 \\
\hline Cellulose $(\mathrm{g} / \mathrm{kg})$ & 50.00 & 50.00 & 50.00 \\
\hline Casein, lactic (g/kg) & 200.00 & 200.00 & 200.00 \\
\hline Grape seed oil $(\mathrm{g} / \mathrm{kg})$ & 42.94 & 34.85 & 26.73 \\
\hline Fish oil (g/kg) & 0.00 & 8.09 & 16.21 \\
\hline $18: 3 n-3(\%)$ & 0.41 & 0.50 & 0.50 \\
\hline $20: 5 n-3(\%)$ & 0.01 & 6.00 & 12.10 \\
\hline $22: 5 n-3(\%)$ & 0.01 & 0.80 & 1.60 \\
\hline $22: 6 n-3(\%)$ & 0.02 & 4.80 & 9.60 \\
\hline SFA $(\%)$ & 10.10 & 10.70 & 14.40 \\
\hline MUFA (\%) & 14.90 & 14.70 & 14.40 \\
\hline n-3 PUFA (\%) & 0.50 & 12.10 & 23.70 \\
\hline n-6 PUFA (\%) & 74.00 & 61.90 & 49.70 \\
\hline Vitamin mixture $(\mathrm{g} / \mathrm{kg})$ & 10.00 & 10.00 & 10.00 \\
\hline Mineral mixture $(\mathrm{g} / \mathrm{kg})$ & 35.00 & 35.00 & 35.00 \\
\hline 1-Cysteine (g/kg) & 3.00 & 3.00 & 3.00 \\
\hline Choline bitartrate $(\mathrm{g} / \mathrm{kg})$ & 2.50 & 2.50 & 2.50 \\
\hline Total (g) & 1000 & 1000 & 1000 \\
\hline
\end{tabular}

$\%$ EPA + DHA relative to the total energy intake in the diet SFA saturated fatty acid, MUFA monounsaturated fatty acid, PUFA polyunsaturated fatty acid

At week 8 , rats were surgically ovariectomized under anesthesia using a combination of Zoletil $(0.25 \mathrm{mg} / \mathrm{kg}$; Carros, France) and Rompun $(10 \mathrm{mg} / \mathrm{kg}$, Bayer Korea, Gyeonggi-do, Korea). From 1 week after ovariectomization, rats ( $n=8$ per group) were randomly assigned to groups injected with either $17 \beta$-estradiol-3-benzoate $\left(E_{2}\right)$ or the vehicle only (corn oil; Sigma-Aldrich, St. Louis, MO, USA) for the last 3 weeks of the study; the six groups were: $0 \% \mathrm{EPA}+$ DHA diet with corn oil injection $(0 \%$ $\mathrm{n}-3), 0 \% \mathrm{EPA}+\mathrm{DHA}$ diet with $\mathrm{E}_{2}$ injection $(0 \%$ $\left.\mathrm{n}-3+\mathrm{E}_{2}\right), 1 \% \mathrm{EPA}+$ DHA diet with corn oil injection $(1 \% \mathrm{n}-3), 1 \% \mathrm{EPA}+$ DHA diet with $\mathrm{E}_{2}$ injection (1\% $\left.\mathrm{n}-3+\mathrm{E}_{2}\right), 2 \% \mathrm{EPA}+$ DHA diet with corn oil injection (2\% n-3), and $2 \%$ EPA + DHA diet with $\mathrm{E}_{2}$ injection $\left(2 \% \mathrm{n}-3+\mathrm{E}_{2}\right)$. Every four days, $1 \mathrm{~mL}$ of corn oil with or without $10 \mu \mathrm{g}$ of $\mathrm{E}_{2}$ was subcutaneously injected to mimic the rat's estrus cycle.

Body weight was measured weekly and dietary intake was measured daily for 12 weeks. At the end of experiment, the rats were fasted overnight and euthanized with Zoletil $(25 \mathrm{mg} / \mathrm{kg})$ and Rompun $(10 \mathrm{mg} / \mathrm{kg})$. Blood samples were collected, and serum and plasma were obtained after centrifugation. Organs were harvested, rinsed with saline, and weighed. Blood and tissue samples were stored at $-80{ }^{\circ} \mathrm{C}$ until analysis. 


\section{Determination of serum and tissue lipid profile}

Serum levels of TG, total cholesterol (TC), and high-density lipoprotein (HDL) cholesterol were determined using commercially available kits (Asan Pharmaceutical Co., Hwaseong, Korea) according to the manufacturer's instructions. Low-density lipoprotein (LDL) cholesterol was calculated using the method by Friedewald et al. (1972).

Hepatic lipid was extracted using the method of Folch et al. (1957). Hepatic content of TG and TC was measured using a commercial kit (Asan Pharmaceutical Co., Hwaseong, Korea).

\section{Analysis of fatty acid composition}

The fatty acid composition of serum was measured as previously described (Harris et al. 2013). Serum was methylated with boron trifluoride-methanol-benzene (Sigma-Aldrich, St. Louis, MO, USA) at $100^{\circ} \mathrm{C}$ for
$45 \mathrm{~min}$. Fatty acid methyl esters were analyzed by gas chromatography (Shimadzu 2010AF; Shimadzu Scientific Instrument, Kyoto, Japan) with a 100-m SP2560 capillary column (Supelco, Bellefonte, PA, USA). Fatty acids were identified by comparison with standards (GLC-727; NuCheck Prep, Elysian, MN, USA). Every batch was analyzed with a quality control sample, and the coefficient of variation was $2.9 \%$.

\section{Western blot analysis}

Liver and skeletal muscle tissues were homogenized in icecold lysis buffer (20 mM HEPES, $0.25 \mathrm{M}$ sucrose, $0.5 \mathrm{mM}$ EDTA, $2 \mathrm{mM}$ dithiothreitol, $1 \mathrm{mM}$ PMSF, $10 \mu \mathrm{g} / \mathrm{mL}$ leupeptin, $10 \mu \mathrm{g} / \mathrm{mL}$ aprotinin, and $1 \mathrm{mM} \mathrm{Na}_{3} \mathrm{VO}_{4}, \mathrm{pH} 7.5$ ) including a phosphatase inhibitor cocktail tablet (Roche Life Science, Basel, Switzerland). The homogenates were centrifuged at $20,000 \times g$ (Eppendorf, Hamburg, Germany) for $60 \mathrm{~min}$ at $4{ }^{\circ} \mathrm{C}$. The supernatants were collected as cytosolic fractions; the pellets were re-suspended in

Table 2 Dietary intake, body weight, and various organ weights

\begin{tabular}{lrrrrcc}
\hline & \multicolumn{1}{c}{$0 \% \mathrm{n}-3$} & \multicolumn{1}{c}{$1 \% \mathrm{n}-3$} & \multicolumn{1}{c}{$2 \% \mathrm{n}-3$} & $0 \% \mathrm{n}-3+\mathrm{E}_{2}$ & $1 \% \mathrm{n}-3+\mathrm{E}_{2}$ & $2 \% \mathrm{n}-3+\mathrm{E}_{2}$ \\
\hline Dietary intake (g/day) & $15.51 \pm 0.21$ & $15.52 \pm 0.11$ & $15.44 \pm 0.08$ & $14.24 \pm 0.09^{*}$ & $14.27 \pm 0.42^{*}$ & $14.44 \pm 0.03^{*}$ \\
Initial body weight (g) & $94.50 \pm 2.00$ & $94.25 \pm 2.95$ & $94.75 \pm 2.54$ & $94.75 \pm 2.21$ & $94.75 \pm 1.79$ & $94.44 \pm 2.00$ \\
Final body weight (g) & $297.75 \pm 3.32$ & $300.25 \pm 3.75$ & $300.63 \pm 6.96$ & $261.00 \pm 3.55^{*}$ & $263.31 \pm 3.36^{*}$ & $263.63 \pm 2.76^{*}$ \\
Liver weight (g) & $6.34 \pm 0.12$ & $6.61 \pm 0.17$ & $6.46 \pm 0.21$ & $6.48 \pm 0.14$ & $6.37 \pm 0.07$ & $6.53 \pm 0.06$ \\
Skeletal muscle weight (g) & $25.45 \pm 0.85$ & $25.76 \pm 0.82$ & $25.33 \pm 0.88$ & $24.86 \pm 0.33$ & $24.89 \pm 0.23$ & $24.75 \pm 0.44$ \\
Kidney weight (g) & $1.69 \pm 0.02$ & $1.65 \pm 0.04$ & $1.68 \pm 0.02$ & $1.70 \pm 0.02$ & $1.68 \pm 0.02$ & $1.72 \pm 0.02$ \\
Visceral fat weight (g) & $4.13 \pm 0.18$ & $4.68 \pm 0.33$ & $4.51 \pm 0.29$ & $2.81 \pm 0.17 *$ & $2.80 \pm 0.14 *$ & $2.71 \pm 0.16^{*}$ \\
Uterus weight (g) & $0.09 \pm 0.00$ & $0.09 \pm 0.00$ & $0.09 \pm 0.00$ & $0.40 \pm 0.01 *$ & $0.40 \pm 0.01 *$ & $0.41 \pm 0.01 *$ \\
\hline
\end{tabular}

Values are mean $\pm \mathrm{SEM} ; 0,1$, and $2 \% \mathrm{n}-3,0,1$, and $2 \% \mathrm{EPA}+$ DHA diet with corn oil injection; 0,1, and $2 \% \mathrm{n}-3+\mathrm{E}_{2}, 0,1$ and $2 \%$ $\mathrm{EPA}+$ DHA diet with $17 \beta$-estradiol-3-benzoate injection

* Values are significantly different $(P<0.05)$ between corn oil and $\mathrm{E}_{2}$ injection for diets containing the same amount of $\mathrm{n}-3$ PUFA

Table 3 Serum lipid profile and hepatic lipid contents

\begin{tabular}{lllllcc}
\hline & $0 \% \mathrm{n}-3$ & $1 \% \mathrm{n}-3$ & $2 \% \mathrm{n}-3$ & $0 \% \mathrm{n}-3+\mathrm{E}_{2}$ & $1 \% \mathrm{n}-3+\mathrm{E}_{2}$ & $2 \% \mathrm{n}-3+\mathrm{E}_{2}$ \\
\hline Serum & & & & & \\
Triglyceride (mmol/L) & $0.64 \pm 0.02$ & $0.57 \pm 0.03^{\dagger}$ & $0.49 \pm 0.02^{\dagger, \dagger \dagger}$ & $0.57 \pm 0.01^{*}$ & $0.49 \pm 0.00^{\dagger, *}$ & $0.44 \pm 0.01^{\dagger, \dagger \dagger, *}$ \\
Total cholesterol (mmol/L) & $2.68 \pm 0.12$ & $2.46 \pm 0.04^{\dagger}$ & $2.16 \pm 0.05^{\dagger, \dagger \dagger}$ & $2.68 \pm 0.07$ & $2.41 \pm 0.06^{\dagger}$ & $2.13 \pm 0.07^{\dagger, \dagger \dagger}$ \\
HDL cholesterol (mmol/L) & $0.66 \pm 0.03$ & $0.68 \pm 0.03$ & $0.65 \pm 0.02$ & $1.05 \pm 0.04^{*}$ & $1.06 \pm 0.04^{*}$ & $1.06 \pm 0.02^{*}$ \\
LDL cholesterol (mmol/L) & $1.62 \pm 0.10$ & $1.38 \pm 0.06^{\dagger}$ & $1.10 \pm 0.06^{\dagger, \dagger \dagger}$ & $1.54 \pm 0.09$ & $1.24 \pm 0.02^{\dagger}$ & $0.91 \pm 0.04^{\dagger, \dagger \dagger}$ \\
Liver & & & & & \\
Triglyceride (mg/g liver) & $65.13 \pm 4.39$ & $55.48 \pm 4.18^{\dagger}$ & $45.86 \pm 3.99^{\dagger, \dagger \dagger}$ & $25.15 \pm 2.19^{*}$ & $15.02 \pm 1.03^{\dagger, *}$ & $14.22 \pm 0.98^{\dagger, *}$ \\
Total cholesterol (mg/g liver) & $61.14 \pm 1.13$ & $56.78 \pm 1.69^{\dagger}$ & $53.82 \pm 0.65^{\dagger}$ & $51.08 \pm 1.82^{*}$ & $45.70 \pm 0.98^{\dagger, *}$ & $44.46 \pm 0.76^{\dagger, *}$ \\
\hline
\end{tabular}

Values are mean \pm SEM; 0,1 , and $2 \% \mathrm{n}-3,0 \% 1 \%$, and $2 \% \mathrm{EPA}+$ DHA diet with corn oil injection; 0,1, and $2 \% \mathrm{n}-3+\mathrm{E} 2,0,1$ and $2 \%$ EPA + DHA diet with $17 \beta$-estradiol-3-benzoate injection

* Values are significantly different $(P<0.05)$ between corn oil and $\mathrm{E}_{2}$ injection for diets containing the same amount of n-3 PUFA

$\dagger$ Values are significantly different $(P<0.05)$ among 0,1 , and $2 \% \mathrm{n}-3$ within the corn oil- and $\mathrm{E}_{2}$-injected groups

$\dagger$ Values are significantly different $(P<0.05)$ between $1 \%$ and $2 \% \mathrm{n}-3$ within the corn oil- and $\mathrm{E}_{2}$-injected groups 
Table 4 Fatty acid composition of serum

\begin{tabular}{|c|c|c|c|c|c|c|}
\hline Fatty acids $(\%)$ & $0 \% \mathrm{n}-3$ & $1 \% \mathrm{n}-3$ & $2 \% \mathrm{n}-3$ & $0 \% \mathrm{n}-3+\mathrm{E}_{2}$ & $1 \% \mathrm{n}-3+\mathrm{E}_{2}$ & $2 \% \mathrm{n}-3+\mathrm{E}_{2}$ \\
\hline $14: 0$ & $0.55 \pm 0.04$ & $0.59 \pm 0.07$ & $0.63 \pm 0.06$ & $0.38 \pm 0.03^{*}$ & $0.43 \pm 0.03 *$ & $0.41 \pm 0.04 *$ \\
\hline $16: 0$ & $19.81 \pm 0.34$ & $19.79 \pm 0.47$ & $20.59 \pm 0.41$ & $17.78 \pm 0.38^{*}$ & $17.98 \pm 0.43^{*}$ & $18.72 \pm 0.27 *$ \\
\hline $16: 1 n-7$ & $1.17 \pm 0.05$ & $1.13 \pm 0.04$ & $1.12 \pm 0.06$ & $0.90 \pm 0.05^{*}$ & $0.91 \pm 0.03 *$ & $0.98 \pm 0.06^{*}$ \\
\hline $18: 0$ & $15.61 \pm 0.34$ & $16.01 \pm 0.50$ & $15.40 \pm 0.22$ & $17.38 \pm 0.51^{*}$ & $17.50 \pm 0.38^{*}$ & $17.03 \pm 0.17 *$ \\
\hline $18: 1 n-9$ & $10.74 \pm 0.44$ & $10.25 \pm 0.71$ & $10.89 \pm 0.45$ & $9.13 \pm 0.74^{*}$ & $8.74 \pm 0.26^{*}$ & $9.32 \pm 0.20^{*}$ \\
\hline $18: 2 n-6$ & $11.21 \pm 0.22$ & $11.88 \pm 0.30$ & $11.41 \pm 0.25$ & $10.56 \pm 0.39$ & $11.48 \pm 0.30$ & $11.67 \pm 0.21$ \\
\hline $18: 3 n-3$ & $0.09 \pm 0.01$ & $0.09 \pm 0.01$ & $0.10 \pm 0.02$ & $0.08 \pm 0.01$ & $0.10 \pm 0.01$ & $0.10 \pm 0.02$ \\
\hline $20: 4 n-6$ & $33.03 \pm 0.77$ & $26.82 \pm 0.77^{\dagger}$ & $21.98 \pm 0.73^{\dagger, \dagger \dagger}$ & $33.95 \pm 0.90$ & $28.05 \pm 0.56^{\dagger}$ & $22.67 \pm 0.30^{\dagger, \dagger \dagger}$ \\
\hline $20: 5 n-3$ & $0.40 \pm 0.13$ & $3.03 \pm 0.18^{\dagger}$ & $6.37 \pm 0.48^{\dagger, \dagger \dagger}$ & $0.24 \pm 0.13$ & $2.79 \pm 0.20^{\dagger}$ & $5.50 \pm 0.44^{\dagger, \dagger \dagger}$ \\
\hline $22: 4 n-6$ & $0.42 \pm 0.04$ & $0.10 \pm 0.01^{\dagger}$ & $0.05 \pm 0.01^{\dagger}$ & $0.48 \pm 0.03$ & $0.13 \pm 0.01^{\dagger}$ & $0.07 \pm 0.02^{\dagger}$ \\
\hline $22: 5 n-6$ & $2.64 \pm 0.35$ & $0.11 \pm 0.02^{\dagger}$ & $0.07 \pm 0.02^{\dagger}$ & $5.73 \pm 0.25^{*}$ & $0.08 \pm 0.01^{\dagger}$ & $0.05 \pm 0.01^{\dagger}$ \\
\hline $22: 5 n-3$ & $0.09 \pm 0.05$ & $0.60 \pm 0.03^{\dagger}$ & $0.91 \pm 0.07^{\dagger, \dagger \dagger}$ & $0.07 \pm 0.04$ & $0.68 \pm 0.03^{\dagger}$ & $1.26 \pm 0.14^{\dagger, \dagger \dagger, *}$ \\
\hline $22: 6 n-3$ & $1.60 \pm 0.29$ & $6.72 \pm 0.29^{\dagger}$ & $7.97 \pm 0.23^{\dagger, \dagger \dagger}$ & $1.27 \pm 0.05$ & $8.52 \pm 0.19^{\dagger, *}$ & $10.25 \pm 0.27^{\dagger, \dagger \dagger, *}$ \\
\hline SFA & $36.66 \pm 0.31$ & $36.86 \pm 0.27$ & $37.03 \pm 0.30$ & $36.08 \pm 0.26$ & $36.27 \pm 0.45$ & $36.39 \pm 0.41$ \\
\hline MUFA & $12.27 \pm 0.42$ & $11.92 \pm 0.69$ & $12.41 \pm 0.45$ & $10.29 \pm 0.74^{*}$ & $10.28 \pm 0.25^{*}$ & $10.65 \pm 0.22 *$ \\
\hline n-3 PUFA & $2.17 \pm 0.45$ & $10.44 \pm 0.38^{\dagger}$ & $15.36 \pm 0.63^{\dagger, \dagger \dagger}$ & $1.66 \pm 0.12$ & $12.08 \pm 0.26^{\dagger, *}$ & $17.12 \pm 0.45^{\dagger, \dagger \dagger, *}$ \\
\hline n-6 PUFA & $48.10 \pm 0.80$ & $39.77 \pm 0.51^{\dagger}$ & $34.27 \pm 0.66^{\dagger, \dagger \dagger}$ & $51.38 \pm 0.65^{*}$ & $40.53 \pm 0.50^{\dagger}$ & $35.16 \pm 0.24^{\dagger, \dagger \dagger}$ \\
\hline
\end{tabular}

Values are mean \pm SEM; 0,1 , and $2 \% \mathrm{n}-3,0,1$, and $2 \%$ EPA + DHA diet with corn oil injection; 0, 1, and $2 \% \mathrm{n}-3+\mathrm{E}_{2}, 0 \% 1 \%$, and $2 \%$ $\mathrm{EPA}+\mathrm{DHA}$ diet with $\mathrm{E}_{2}$ injection

$P U F A$ polyunsaturated fatty acid, $S F A$ saturated fatty acid, MUFA monounsaturated fatty acid

* Values are significantly different $(P<0.05)$ between corn oil and $\mathrm{E}_{2}$ injection for diets containing the same amount of $\mathrm{n}-3$ PUFA

$\dagger$ Values are significantly different $(P<0.05)$ among 0,1 , and $2 \% \mathrm{n}-3$ within the corn oil- and $\mathrm{E}_{2}$-injected groups

$\dagger$ Values are significantly different $(P<0.05)$ between $1 \%$ and $2 \% \mathrm{n}-3$ within the corn oil- and $\mathrm{E}_{2}$-injected groups

$250 \mu \mathrm{L}$ of lysis buffer with $1 \%(\mathrm{v} / \mathrm{v})$ triton X-100 and then centrifuged at 20,000 $\times g$ (Eppendorf, Hamburg, Germany) for $30 \mathrm{~min}$ at $4{ }^{\circ} \mathrm{C}$ to obtain nuclear fractions.

The protein concentrations of each fraction were determined by the Bradford method using bovine serum albumin (Bio-Rad, Hercules, CA, USA) as a standard. Aliquots of the lysates (30-80 $\mu \mathrm{g}$ of protein) were separated on an $8 \%$ SDS-PAGE gel, transferred to a polyvinylidene fluoride membrane $(0.45 \mu \mathrm{m}$, Merck Millipore, Billerica, MA, USA), and blocked for $1 \mathrm{~h}$ at room temperature with $5 \%$ skim milk in Tris-buffered saline containing Tween-20 (TBST). After blocking, the membranes were incubated overnight with a primary antibody SREBP1 (1:1000), PPAR $\alpha$ (1:1000), CPT1a (1:1000), estrogen receptor $\alpha(E R \alpha ; 1: 500), \operatorname{ER} \beta$ (1:500), ACC1 (1:1000), FAS (1:1000), AMPK (1:1000), phosphorylated AMPK (p-AMPK; 1:1000), signal transducers and activators of transcription 3 (STAT3; 1:1000), phosphorylated STAT3 (p-STAT3; 1:500), DGAT2 (1:200), and CPT1m $(1: 100)$ in TBST at $4{ }^{\circ} \mathrm{C}$. The antibodies for SREBP1, PPAR $\alpha, C P T 1 a, E R \alpha$, and ER $\beta$ were purchased from Abcam (Cambridge, UK). The antibodies for ACC1, FAS, AMPK, p-AMPK, STAT3, and p-STAT3 were purchased from Cell Signaling Technology (Beverly, MA, USA), and those for CPT1m and DGAT2 were purchased from Santa Cruz Biotechnology (Santa Cruz, CA, USA). After rinsing in TBST, the membranes were incubated with horseradish peroxidase-conjugated goat anti-rabbit $(1: 10,000$, Cell Signaling Technology, Beverly, MA, USA) or anti-mouse IgG (1:5000, Enzo Life Science, Farmingdale, NY, USA) for $1 \mathrm{~h}$ at room temperature. The membranes were reacted with a chemiluminescence kit (GE Healthcare Life Sciences, Piscataway, NJ, USA), and immunoreactive bands were visualized using the UV setting on a ChemiDoc MP Imaging System (Bio-Rad, Hercules, CA, USA) to estimate total protein per lane. $\beta$-Actin $(1: 1000$, BD Transduction Laboratories, NJ, USA) was used for normalization.

\section{Statistical analysis}

Values were expressed as the mean \pm standard error of the mean (SEM), and differences were considered significant at $P<0.05$. Data were analyzed using a two-way analysis of variance (ANOVA) with factors of $n-3$ PUFA supplementation and $E_{2}$ injection, followed by Duncan's post hoc test. Analysis was done using SPSS for Windows, version 18.0 (SPSS Inc., Chicago, IL, USA). 

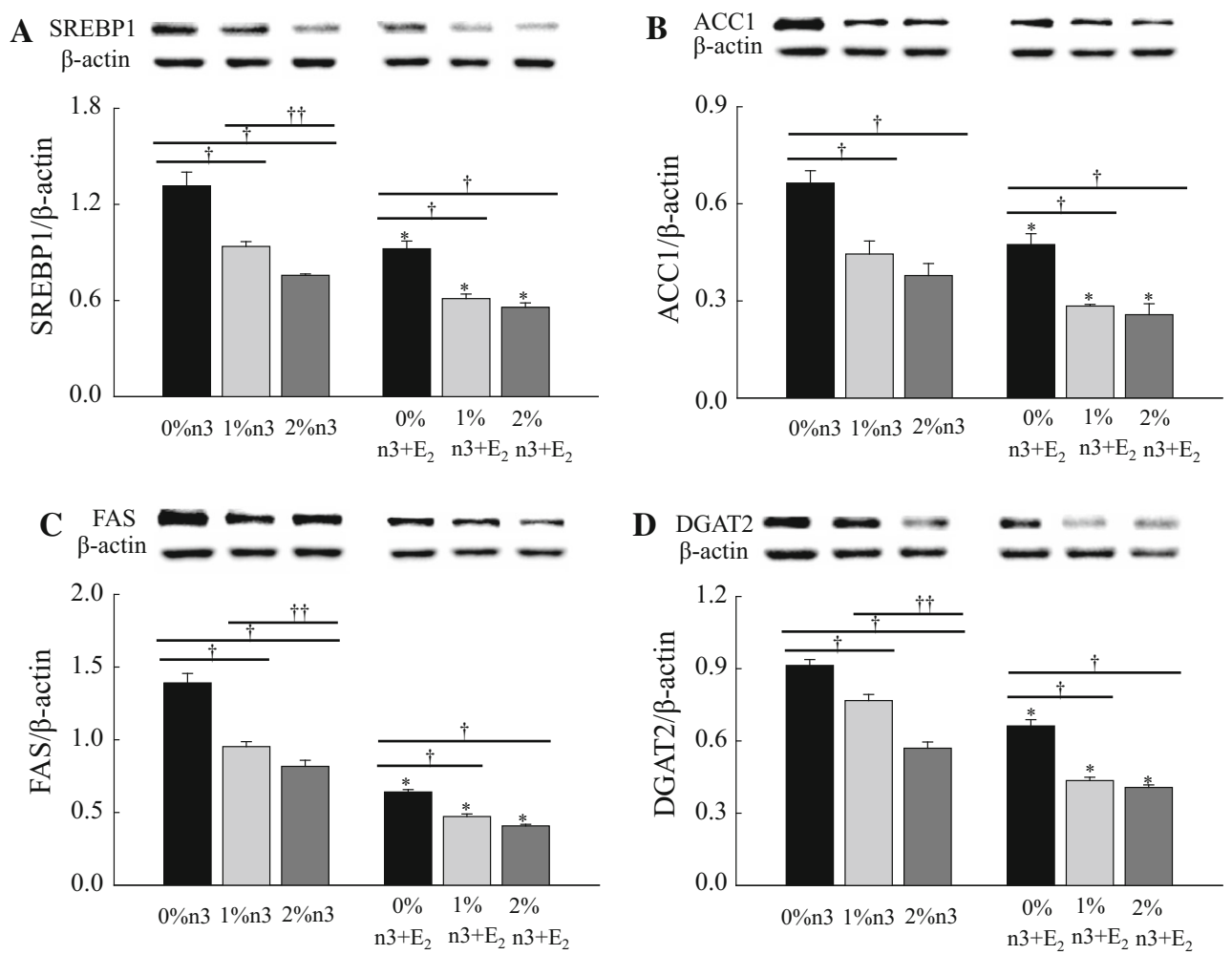

Fig. 1 Effects of n-3 polyunsaturated fatty acid and 17 $\beta$-estradiol-3benzoate $\left(\mathrm{E}_{2}\right)$ on the expression of sterol regulatory element-binding protein 1 (SREBP1, a), acetyl-CoA carboxylase 1 (ACC1, b), fatty acid synthase (FAS, c), and diacylglycerol acyltransferase 2 (DGAT2, d) in liver. Values are expressed as mean $\pm \operatorname{SEM}(n=8) ; 0,1$, and $2 \% \mathrm{n}-3,0,1$, and $2 \%$ EPA + DHA diets with corn oil injection; 0, 1 , and $2 \% \mathrm{n}-3+\mathrm{E}_{2}, 0,1$ and $2 \% \mathrm{EPA}+\mathrm{DHA}$ diets with $\mathrm{E}_{2}$

\section{Results}

\section{Dietary intake, body weight, and organ weights}

Regardless of n-3 PUFA supplementation, the rats injected with $\mathrm{E}_{2}$ consumed less food $\left(F_{1,42}=130.2, P<0.0001\right)$, had a lower final body weight $\left(F_{1,42}=116.8, P<0.0001\right)$, and had less visceral fat $\left(F_{1,42}=82.8, P<0.0001\right)$ (Table 2). However, the uterus weights were heavier in rats injected with $\mathrm{E}_{2}$ than in those injected with corn oil, regardless of $\mathrm{n}-3$ PUFA supplementation $\left(F_{1,42}=2123.5\right.$, $P<0.0001)$. There were no significant differences in initial body weights or final weights of liver, skeletal muscle, or kidney.

\section{Serum lipid profile and hepatic lipid contents}

Supplementation with n-3 PUFA significantly decreased serum concentrations of TG $\left(F_{2,42}=37.0, P<0.0001\right)$, TC $\left(F_{2,42}=27.0, P<0.0001\right)$, and LDL cholesterol $\left(F_{2,42}=37.5, \quad P<0.0001\right)$ regardless of $\mathrm{E}_{2}$ injection (Table 3). The hepatic contents of TG and TC were also

injection. Asterisk values are significantly different $(P<0.05)$ between corn oil and $E_{2}$ injection for diets containing the same amount of n-3 PUFA. Dagger values are significantly different $(P<0.05)$ among 0,1 , and $2 \% \mathrm{n}-3$ within the corn oil- and $\mathrm{E}_{2^{-}}$ injected groups. Double dagger values are significantly different $(P<0.05)$ between $1 \%$ and $2 \% \mathrm{n}-3$ within the corn oil- or $\mathrm{E}_{2^{-}}$ injected groups

decreased by n-3 PUFA supplementation with or without $\mathrm{E}_{2}$ injection. Interestingly, there were dose-dependent effects of n-3 PUFA supplementation on serum concentrations of TG, TC, and LDL cholesterol as well as hepatic TG content.

$\mathrm{E}_{2}$ injections significantly decreased the serum concentration of TG $\left(F_{1,42}=24.2, P<0.0001\right)$ and the hepatic contents of TG $\left(F_{1,42}=211.3, P<0.0001\right)$ and TC $\left(F_{1,42}=98.8, P<0.0001\right)$. The injections also increased serum HDL cholesterol concentrations $\left(F_{1,42}=156.3\right.$, $P<0.0001)$. However, there was no significant interaction between n-3 PUFA and $E_{2}$ injection on lipid profile or hepatic lipid contents (Table 3).

\section{Serum fatty acid composition}

Supplementation with n-3 PUFA significantly decreased the serum level of $20: 4 \mathrm{n}-6\left(F_{2,42}=127.3, P<0.0001\right)$, 22:4n-6 $\quad\left(F_{2,42}=162.3, \quad P<0.0001\right), \quad$ and $22: 5 \mathrm{n}-6$ $\left(F_{2,42}=364.1, P<0.0001\right)$, while it increased circulating concentrations of $20: 5 \mathrm{n}-3 \quad\left(F_{2,42}=177.3, \quad P<0.0001\right)$ (Table 4). Regardless of n-3 PUFA supplementation, $E_{2}$ 



Fig. 2 Effects of n-3 polyunsaturated fatty acid and 17 $\beta$-estradiol-3benzoate $\left(E_{2}\right)$ on the expressions of phosphorylated adenosine monophosphate-activated protein kinase (p-AMPK, a), AMPK (b), peroxisomal proliferator-activated receptor $\alpha$ (PPAR, c), and carnitine palmitoyltransferase 1a (CPT1a, d) in liver. Values are expressed as mean $\pm \operatorname{SEM}(n=8) ; 0,1$, and $2 \% \mathrm{n}-3,0,1$, and $2 \%$ EPA + DHA diets with corn oil injection; 0,1 , and $2 \% \mathrm{n}-3+\mathrm{E}_{2}, 0,1$ and $2 \%$

injection significantly decreased the serum level of 14:0 $\left(F_{1,42}=22.8, \quad P<0.0001\right), \quad 16: 0 \quad\left(F_{1,42}=36.5, \quad P<\right.$ $0.0001), \quad 16: 1 \mathrm{n}-7 \quad\left(F_{1,42}=26.5, \quad P<0.0001\right), \quad 18: 1 \mathrm{n}-9$ $\left(F_{1,42}=14.3, P=0.0005\right)$, and monounsaturated fatty acid $\left(F_{1,42}=19.0, P<0.0001\right)$, while it increased the serum level of 18:0 $\left(F_{1,42}=28.3, P<0.0001\right)$. Both n-3 PUFA supplementation and $E_{2}$ injection significantly increased serum levels of 22:5n-3 $\quad\left(F_{2,42}=100.5\right.$, $P<0.0001$ and $\mathrm{F}_{1,42}=5.31, P=0.026$, respectively), 22:6n-3 $\left(F_{2,42}=597.5, P<0.0001\right.$ and $F_{1,42}=42.5$, $P<0.0001$, respectively), and total n-3 PUFA $\left(F_{2,42}=616.6, P<0.0001\right.$ and $F_{1,42}=8.0, P=0.007$, respectively). Accordingly, n-3 PUFA supplementation and $\mathrm{E}_{2}$ injection both significantly decreased total n-6 PUFA $\left(F_{2,42}=334.3, \quad P<0.0001 \quad\right.$ and $F_{1,42}=11.7, \quad P=$ 0.0014). In addition, there were interactions between n-3 PUFA supplementation and $\mathrm{E}_{2}$ injection on the serum level of $\quad 22: 5 \mathrm{n}-6 \quad\left(F_{2,42}=52.1, \quad P<0.0001\right), \quad 22: 6 \mathrm{n}-3$ $\left(F_{2,42}=17.4, \quad P<0.0001\right), \quad$ and total n-3 PUFA $\left(F_{2,42}=4.78, P=0.0135\right)$. There were also dose-dependent effects of n-3 PUFA on the serum level of 20:4n-6, 20:5n-3, 22:5n-3, and 22:6n-3.

$\mathrm{EPA}+\mathrm{DHA}$ diets with $\mathrm{E}_{2}$ injection. Asterisk values are significantly different $(P<0.05)$ between corn oil and $\mathrm{E}_{2}$ injection for diets containing the same amount of n-3 PUFA. Dagger values are significantly different $(P<0.05)$ among 0,1 , and $2 \%$ n-3 within the corn oil- and $\mathrm{E}_{2}$-injected groups. Double dagger values are significantly different $(P<0.05)$ between 1 and $2 \%$ n-3 within the corn oil- or $\mathrm{E}_{2}$-injected groups

\section{Protein expression in liver and muscle}

Both n-3 PUFA supplementation and $E_{2}$ injection significantly decreased the hepatic expression of SREBP1 $\left(F_{2,42}=53.0, P<0.0001\right.$ and $F_{1,42}=64.7, P<0.0001$, respectively $)$ ACC1 $\left(F_{2,42}=31.7, \quad P<0.0001\right.$ and $F_{1,42}=32.8, \quad P<0.0001$, respectively $)$, FAS $\left(F_{2,42}=\right.$ 66.4, $P<0.0001$ and $F_{1,42}=337.4, P<0.0001$, respectively $)$ and DGAT2 $\left(F_{2,42}=91.5, \quad P<0.0001\right.$ and $F_{1,42}=185.6, P<0.0001$, respectively) (Fig. 1). Dosedependent effects of n-3 PUFA were observed on the expression of SREBP1, FAS, and DGAT2 only in corn oilinjected rats. Additionally, there were interactions between n-3 PUFA and $\mathrm{E}_{2}$ injection on FAS $\left(F_{2,42}=12.2\right.$, $P<0.0001)$ and DGAT2 $\left(F_{2,42}=7.18, P=0.0021\right)$.

Both n-3 PUFA supplementation and $E_{2}$ injection increased hepatic expression of p-AMPK $\left(F_{2,42}=16.5\right.$, $P<0.0001$ and $F_{1.42}=75.9, P<0.0001$, respectively), AMPK $\quad\left(F_{2,42}=15.8, \quad P<0.0001\right.$ and $F_{1,42}=64.7$, $P<0.0001, \quad$ respectively $), \quad$ PPAR $\alpha \quad\left(F_{2,42}=22.0\right.$, $P=0.0001$ and $F_{1,42}=18.0, P<0.0001$, respectively), and CPT1a $\left(F_{2,42}=8.43, P=0.0008\right.$ and $F_{1,42}=19.7$, 


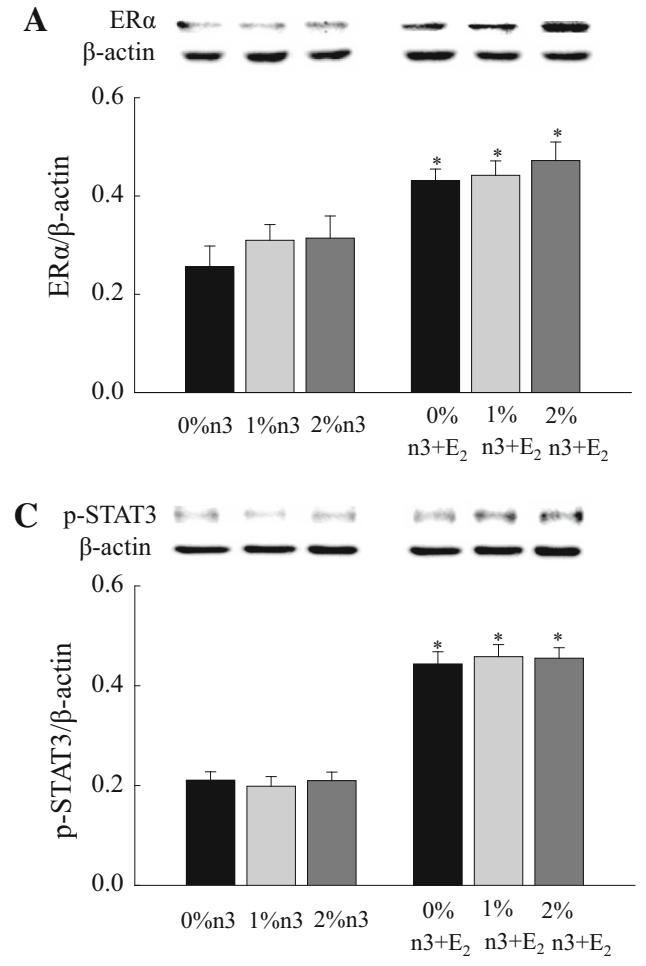

Fig. 3 Effects of 17 $\beta$-estradiol-3-benzoate $\left(E_{2}\right)$ on the expression of estrogen receptor $\alpha(\mathrm{ER} \alpha, \mathbf{a}), \operatorname{ER} \beta$ (b), phosphorylated signal transducers and activators of transcription 3 (p-STAT3, c), and STAT3 $(\mathbf{d})$ in liver. Values are expressed as mean $\pm \operatorname{SEM}(n=8) ; 0$, 1 , and $2 \% \mathrm{n}-3,0,1$, and $2 \% \mathrm{EPA}+\mathrm{DHA}$ diets with corn oil

$P<0.0001$, respectively) (Fig. 2). The effect of n-3 PUFA on the expression of PPAR $\alpha$ was dose-dependent in both corn oil- and $\mathrm{E}_{2}$-injected rats.

Regardless of $n-3$ PUFA supplementation, the $E_{2}$ injection increased the hepatic expression of $\mathrm{ER} \alpha$ $\left(F_{1,42}=24.00, \quad P<0.0001\right), \quad$ ER $\beta \quad\left(F_{1,42}=34.5\right.$, $P<0.0001)$, p-STAT3 $\left(F_{1,42}=211.6, P<0.0001\right)$, and STAT3 $\left(F_{1,42}=481.4, P<0.0001\right)$ (Fig. 3$)$. Similar to hepatic expression, both n-3 PUFA supplementation and $\mathrm{E}_{2}$ injection increased muscle expression of p-AMPK $\left(F_{2,42}=13.5, P<0.0001\right.$ and $F_{1,42}=41.0, P<0.0001$, respectively), AMPK $\left(F_{2,42}=11.1, \quad P=0.0001\right.$ and $F_{1,42}=53.8, P<0.0001$, respectively $), \operatorname{PPAR} \alpha\left(F_{2,42}=\right.$ $20.8, P<0.0001$ and $F_{1,42}=31.1, P<0.0001$, respectively $)$ and $\mathrm{CPT} 1 \mathrm{~m} \quad\left(F_{2,42}=17.7, \quad P<0.0001\right.$ and $F_{1,42}=22.3, P<0.0001$, respectively) (Fig. 4).

$\mathrm{E}_{2}$ injection increased muscle expression of ER $\alpha$ in both the cytosol and the nucleus $\left(F_{1,24}=271.9, P<0.0001\right.$ and $F_{1,42}=297.6, P<0.0001$, respectively $)$ and $\operatorname{ER} \beta\left(F_{1,42}\right.$ $=159.5, \quad P<0.0001$ and $F_{1,42}=126.5, \quad P<0.0001$, respectively) (Fig. 5). Also, in both the cytosol and the nucleus, n-3 PUFA supplementation increased the expression of $\mathrm{ER} \alpha\left(F_{2,42}=19.6, P<0.0001\right.$ and $F_{2,42}=11.49$, $P=0.0001, \quad$ respectively $)$ and $\operatorname{ER} \beta \quad\left(F_{2,42}=67.9\right.$,
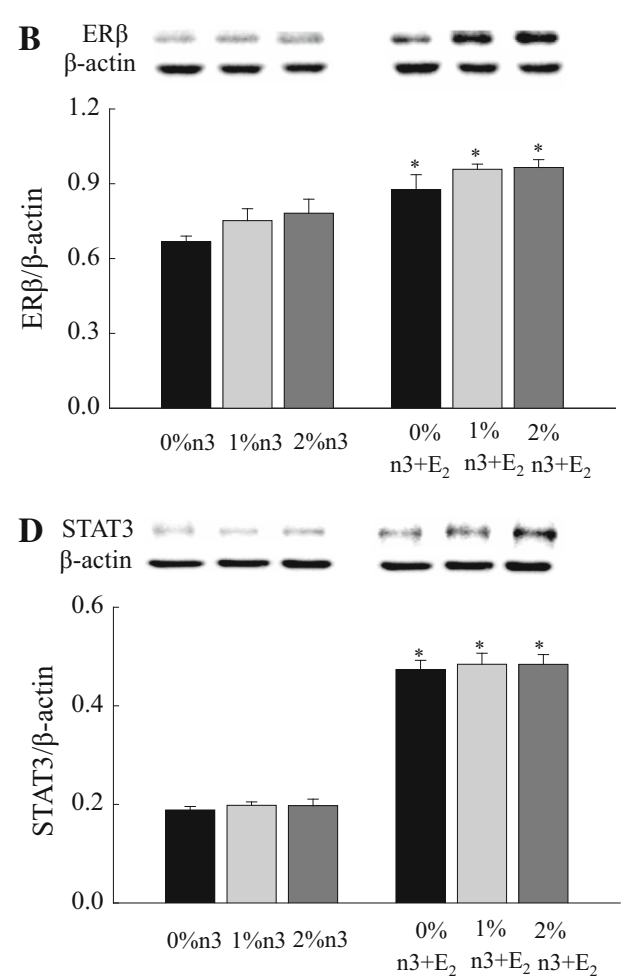

injection; 0, 1, and $2 \% \mathrm{n}-3+\mathrm{E}_{2}, 0,1$, and $2 \% \mathrm{EPA}+$ DHA diets with $\mathrm{E}_{2}$ injection. Asterisk Values are significantly different $(P<0.05)$ between corn oil and $\mathrm{E}_{2}$ injection for diets containing the same amount of n-3 PUFA

$P<0.0001$ and $F_{2,42}=9.19, P=0.0005$, respectively) in muscle.

\section{Discussion}

This was the first study to report that n-3 PUFA supplementation and $E_{2}$ injection had a synergic effect on hypertriglyceridemia through modulating protein expression related to TG synthesis and $\beta$-oxidation in liver and skeletal muscle of OVX rats. Additionally, there were interactions between n-3 PUFA supplementation and $E_{2}$ injection on the hepatic expression of FAS and DGAT2.

Previous studies consistently observed that the supplementation of n-3 PUFA containing EPA and DHA significantly reduced blood concentrations of TG, TC, and LDL cholesterol in animals (Harris and Bulchandani 2006; Boschetti et al. 2013) and humans (Ras et al. 2014). The present study also showed that n-3 PUFA supplementation significantly and dose-dependently reduced serum and liver levels of lipids.

The hypotriglyceridemic effect of n-3 PUFA supplementation is apparently due to a decrease in hepatic expression of SREBP1 (Lu et al. 2011; Sekiya et al. 2003), 

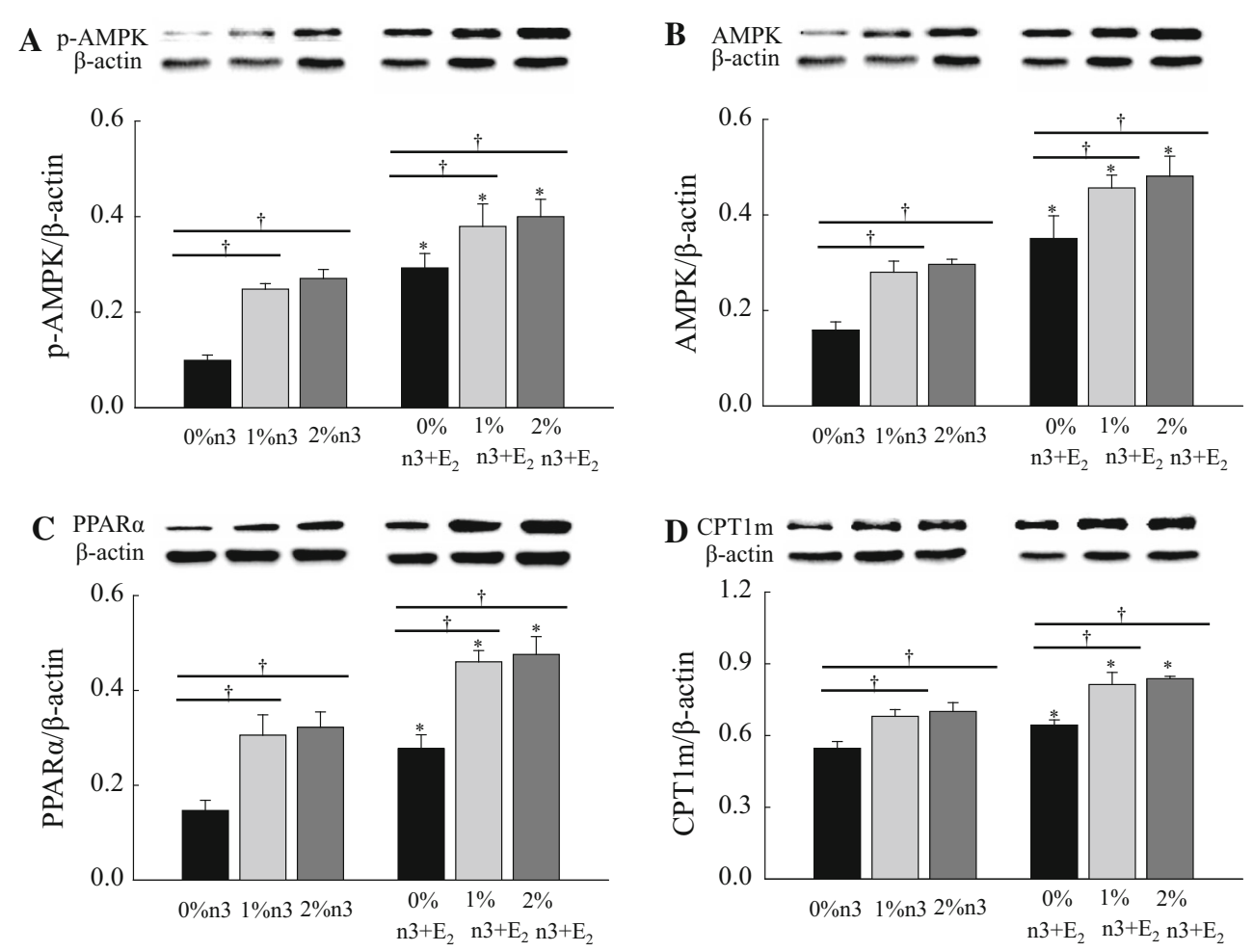

Fig. 4 Effects of n-3 polyunsaturated fatty acid and 17 $\beta$-estradiol-3benzoate $\left(E_{2}\right)$ on the expressions of phosphorylated adenosine monophosphate-activated protein kinase (p-AMPK, a), AMPK (b), peroxisomal proliferator-activated receptor $\alpha(\operatorname{PPAR} \alpha, \mathbf{c})$, and carnitine palmitoyltransferase $1 \mathrm{~m}(\mathrm{CPT} 1 \mathrm{~m}, \mathbf{d})$ in skeletal muscle. Values are expressed as mean $\pm \operatorname{SEM}(n=8) ; 0,1$, and $2 \% \mathrm{n}-3,0$,

1 , and $2 \% \mathrm{EPA}+$ DHA diets with corn oil injection; 0,1 , and $2 \%$ $\mathrm{n}-3+\mathrm{E}_{2}, 0,1$, and $2 \% \mathrm{EPA}+$ DHA diets with $\mathrm{E}_{2}$ injection. Asterisk values are significantly different $(P<0.05)$ between corn oil and $\mathrm{E}_{2}$ injection for diets containing the same amount of n-3 PUFA. Dagger values are significantly different $(P<0.05)$ among 0,1 , and $2 \% \mathrm{n}-3$ within the corn oil- or $\mathrm{E}_{2}$-injected groups

ACC1 (Zhang et al. 2014), and FAS (Lu et al. 2011; Zhang et al. 2014) in the rodent model, which was also observed in the present study. A systematic review reported that n-3 PUFA supplementation also decreases activity of DGAT, the final step in TG synthesis in the liver (Harris and Bulchandani 2006). Consistently, the present study also showed that hepatic expression of DGAT2 decreased dosedependently with n-3 PUFA supplementation.

In addition to TG synthesis, it has been suggested that the hypotriglyceridemic effect of n-3 PUFA supplementation is due to increased $\beta$-oxidation in liver and skeletal muscle (Ukropec et al. 2003). Indeed, n-3 PUFA supplementation has been shown to increase expression of PPAR $\alpha$, p-AMPK, and CPT1 in liver or/and skeletal muscle of rats (Gonzalez-Manan et al. 2012; Motawi et al. 2009). In line with these results, the present study showed that n-3 PUFA supplementation up-regulated the expression of PPAR $\alpha$, CPT1, p-AMPK, and AMPK in liver and/ or skeletal muscle of OVX rats.

Previous studies have reported that $\mathrm{E}_{2}$ directly downregulates SREBP1 (D'Eon et al. 2005; Paquette et al. 2008) and its downstream targets ACC1 and FAS (D'Eon et al. 2005) in the liver of OVX rats, suggesting that $E_{2}$ also

reduces hepatic synthesis of fatty acids. Although Zhu et al. (2013) reported that hepatic DGAT2 expression did not change in OVX rats with or without $\mathrm{E}_{2}$ injection, they reported that $\mathrm{E}_{2}$ injection inhibited hepatic accumulation of diacylglycerol. In the present study, $\mathrm{E}_{2}$ injection significantly reduced the hepatic expression of DGAT2, suggesting that $E_{2}$ decreased not only fatty acid synthesis but also TG synthesis. Consistent with our findings, previous studies have shown that $E_{2}$ decreased hepatic TG deposition and, in turn, reduced serum levels of TG (Zhu et al. 2013; Zoth et al. 2010). Additionally, decreased fat mass by $E_{2}$ in the present study could be related to adipocyte lipoprotein lipase since Mayes and Watson (2004) reported that $E_{2}$ decreased fatty acid uptake and accumulation by reducing adipocyte lipoprotein lipase activity.

Herein, $E_{2}$ injection stimulated $\beta$-oxidation and therefore reduced the availability of substrate for TG synthesis. Consistent with this result, previous studies showed that $\mathrm{E}_{2}$ injection increased the expression of PPAR $\alpha$, AMPK, and CPT1 in liver and/or skeletal muscle (D'Eon et al. 2005; Paquette et al. 2008; Kim et al. 2010).

It has been shown that $E_{2}$ exerts its physiological effects via the two nuclear receptors ER $\alpha$ and ER $\beta$ (Dahlman- 

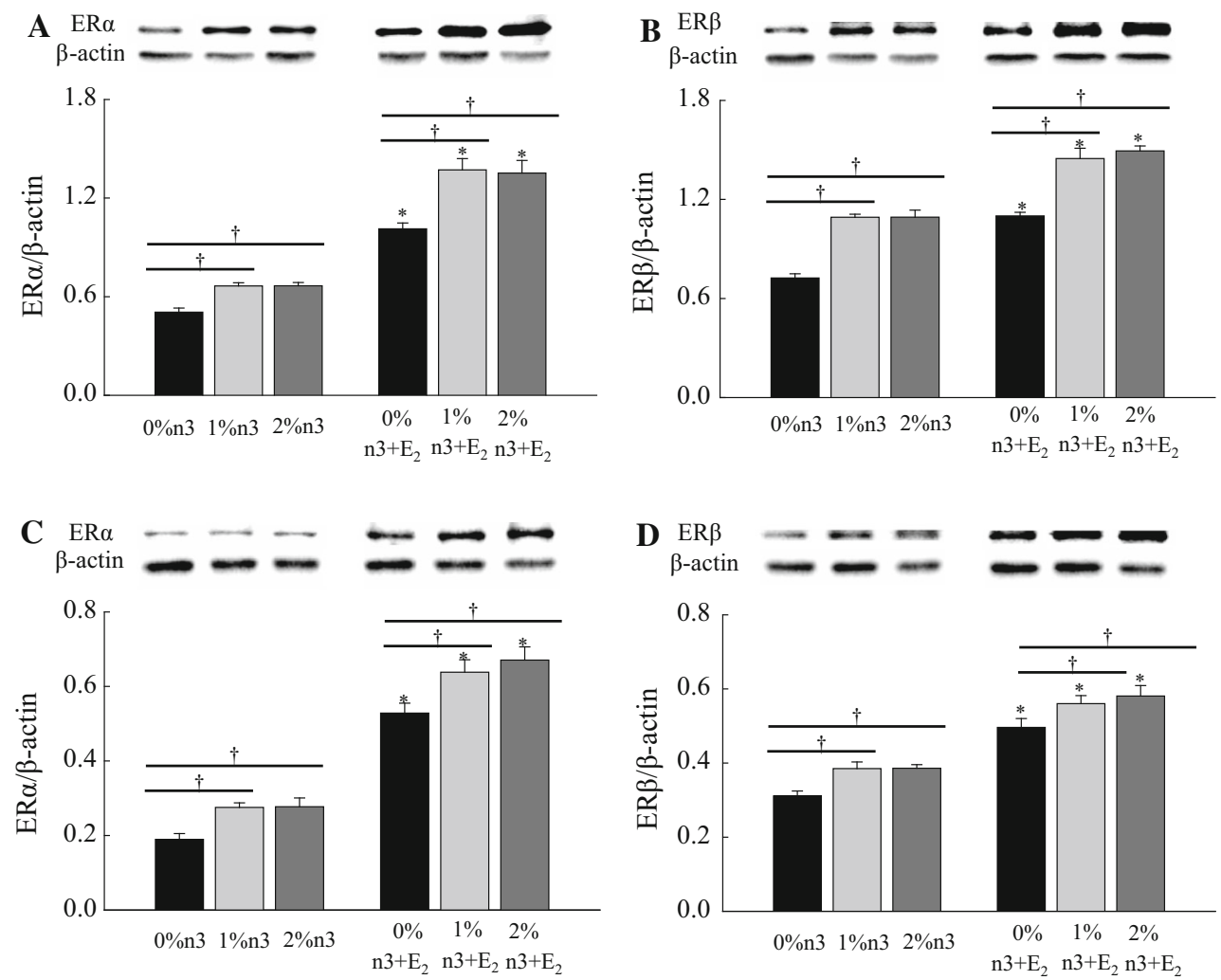

Fig. 5 Effects of n-3 polyunsaturated fatty acid and $17 \beta$-estradiol-3benzoate $\left(\mathrm{E}_{2}\right)$ on the expressions of estrogen receptor $(\mathrm{ER})$ in skeletal muscle. Cytosol fraction of $\operatorname{ER} \alpha(\mathbf{a})$ and $\operatorname{ER} \beta$ (b) and nuclear fraction of $\operatorname{ER} \alpha(\mathbf{c})$ and $\operatorname{ER} \beta$ (d). Values are expressed as mean \pm SEM $(n=8) ; 0,1$, and $2 \% \mathrm{n}-3,0,1$, and $2 \% \mathrm{EPA}+$ DHA diets with corn oil injection; 0,1 , and $2 \% \mathrm{n}-3+\mathrm{E}_{2}, 0,1$, and $2 \%$

Wright et al. 2006). In the present study, $E_{2}$ injection increased expression of ER $\alpha$ and ER $\beta$ both in liver and skeletal muscle. Interestingly, for the first time, the present study reports that n-3 PUFA supplementation also increased the expression of these receptors, but in skeletal muscle only, but not in liver. ER expression has been suggested to be tissue specific. For example, in one study, ER expression was highly sensitive to sexual steroids in muscle, but not in liver (Pfaffl et al. 2001). The present study also showed that ER $\alpha$ and ER $\beta$ were present in both nuclear and cytosolic compartments, but, in skeletal muscle, localization was preferential to the cytosol, which includes the cellular membrane. Therefore, the effect of n-3 PUFAs on ERs could be indirect, because n-3 PUFA can incorporate into the cell membrane and affect membrane fluidity and permeability (Senkal et al. 2007; Armstrong et al. 2003).

The present study suggests that the hypotriglyceridemic effects of n-3 PUFA supplementation and $E_{2}$ injection were synergistic. Both n-3 PUFA supplementation and $E_{2}$ injection suppressed TG synthesis and accelerated $\beta$-oxidation through a similar pathway, and thus, the

$\mathrm{EPA}+$ DHA diets with $\mathrm{E}_{2}$ injection. Asterisk values are significantly different $(P<0.05)$ between corn oil and $\mathrm{E}_{2}$ injection for diets containing the same amount of n-3 PUFA. Dagger values are significantly different $(P<0.05)$ among 0,1 , and $2 \%$ n-3 within the corn oil- or $\mathrm{E}_{2}$-injected groups

combination of both treatments had further effects on TG metabolism.

In addition, the present study showed that there is an interaction between n-3 PUFA supplementation and $E_{2}$ injection on the hepatic expression of FAS and DGAT2. A previous study reported that the binding of $\mathrm{E}_{2}$ to the ER induces phosphorylation of signal transducer and activator of transcription 3 (STAT3), which reduces FAS expression in liver (Gao et al. 2006; Tiano et al. 2011). STAT3 has been shown to decrease TG synthesis, which is independent of the fatty acid synthesis pathway through SREBP1 (Kinoshita et al. 2008). The present study suggests that the interaction between $n-3$ PUFA supplementation and $E_{2}$ injection on the expression of FAS might stem from $E_{2}-$ induced expression of STAT3, but not from effects induced by $n-3$ PUFA. In addition, the interaction between $n-3$ PUFA and $E_{2}$ may have arisen from effects on DGAT2, which is a downstream target of FAS.

In line with published literature, the present study showed that n-3 PUFA supplementation dose-dependently increased serum levels of n-3 PUFA, but decreased n-6 levels. $E_{2}$ is known to activate the conversion of $\alpha$-linolenic 
acid to a longer chain n-3 PUFAs by stimulating desaturation, elongation, and $\beta$-oxidation (Burdge and Calder 2005; Extier et al. 2010). Indeed, the present study showed a synergic effect of n-3 PUFA supplementation and $E_{2}$ injection on serum concentrations of $22: 5, \mathrm{n}-6 ; 22: 5$, n-3; and 22:6, n-3. Additionally, serum levels of 14:0; 16:0; and 18:1, n-9 were lower, but levels of 18:0 were higher in $E_{2^{-}}$ injected rats in the present study, which was likely due to activation of elongase 6 and inactivation of stearoyl-CoA desaturase by $\mathrm{E}_{2}$ (Marks et al. 2013).

The present study demonstrated that n-3 PUFA supplementation and $E_{2}$ injection had a synergic effect on hypotriglyceridemia through both suppressing fatty acid and TG synthesis and accelerating $\beta$-oxidation in OVX rat. Further studies are needed to clarify the mechanism by which n-3 PUFA supplementation increases the expression of ERs in skeletal muscle.

Acknowledgments This work was supported by a grant from the Korea Research Foundation (NRF-2012R1A1A2040553) funded by the Korean government.

\section{Compliance with ethical standards}

Conflict of interest Suhyun Kim, Youri Jin, and Yongsoon Park declare that they have no conflict of interest.

\section{References}

Armstrong VT, Brzustowicz MR, Wassall SR, Jenski LJ, Stillwell W (2003) Rapid flip-flop in polyunsaturated (docosahexaenoate) phospholipid membranes. Arch Biochem Biophys 414(1):74-82

Bayturan O, Tuzcu EM, Lavoie A, Hu T, Wolski K, Schoenhagen P, Kapadia S, Nissen SE, Nicholls SJ (2010) The metabolic syndrome, its component risk factors, and progression of coronary atherosclerosis. Arch Intern Med 170(5):478-484. doi:10.1001/archinternmed.2009.551

Boschetti E, Di Nunzio M, Danesi F, Tugnoli V, Bordoni A (2013) Influence of genotype on the modulation of gene and protein expression by $n-3$ LC-PUFA in rats. Genes Nutr 8(6):589-600. doi:10.1007/s12263-013-0349-3

Burdge GC, Calder PC (2005) Conversion of alpha-linolenic acid to longer-chain polyunsaturated fatty acids in human adults. Reprod Nutr Dev 45(5):581-597. doi:10.1051/rnd:2005047

Chapman MJ, Ginsberg HN, Amarenco P, Andreotti F, Boren J, Catapano AL, Descamps OS, Fisher E, Kovanen PT, Kuivenhoven JA et al (2011) Triglyceride-rich lipoproteins and highdensity lipoprotein cholesterol in patients at high risk of cardiovascular disease: evidence and guidance for management. Eur Heart J 32(11):1345-1361. doi:10.1093/eurheartj/ehr112

Dahlman-Wright K, Cavailles V, Fuqua SA, Jordan VC, Katzenellenbogen JA, Korach KS, Maggi A, Muramatsu M, Parker MG, Gustafsson JA (2006) International union of pharmacology LXIV. Estrogen receptors. Pharmacol Rev 58(4):773-781. doi:10.1124/pr.58.4.8

D'Eon TM, Souza SC, Aronovitz M, Obin MS, Fried SK, Greenberg AS (2005) Estrogen regulation of adiposity and fuel partitioning evidence of genomic and non-genomic regulation of lipogenic and oxidative pathways. J Biol Chem 280(43):35983-35991. doi:10.1074/jbc.M507339200

Eslick GD, Howe PR, Smith C, Priest R, Bensoussan A (2009) Benefits of fish oil supplementation in hyperlipidemia: a systematic review and meta-analysis. Int $J$ Cardiol 136(1):4-16. doi:10.1016/j.ijcard.2008.03.092

Extier A, Langelier B, Perruchot MH, Guesnet P, Van Veldhoven PP, Lavialle M, Alessandri JM (2010) Gender affects liver desaturase expression in a rat model of $\mathrm{n}-3$ fatty acid repletion. J Nutr Biochem 21(3):180-187. doi:10.1016/j.jnutbio.2008.10.008

Folch J, Lees M, Sloane S, Stanley GH (1957) A simple method for the isolation and purification of total lipides from animal tissues. J Biol Chem 226:497-509

Friedewald WT, Levy RI, Fredrickson DS (1972) Estimation of the concentration of low-density lipoprotein cholesterol in plasma, without use of the preparative ultracentrifuge. Clin Chem 18(6):499-502

Furusyo N, Ai M, Okazaki M, Ikezaki H, Ihara T, Hayashi T, Hiramine S, Ura K, Kohzuma T, Schaefer EJ et al (2013) Serum cholesterol and triglyceride reference ranges of twenty lipoprotein subclasses for healthy Japanese men and women. Atherosclerosis 231(2):238-245. doi:10.1016/j.atherosclerosis. 2013.09.008

Gao H, Bryzgalova G, Hedman E, Khan A, Efendic S, Gustafsson JA, Dahlman-Wright K (2006) Long-term administration of estradiol decreases expression of hepatic lipogenic genes and improves insulin sensitivity in ob/ob mice: a possible mechanism is through direct regulation of signal transducer and activator of transcription 3. Mol Endocrinol. 20(6):1287-1299. doi:10.1210/ me.2006-0012

Gonzalez-Manan D, Tapia G, Gormaz JG, D'Espessailles A, Espinosa A, Masson L, Varela P, Valenzuela A, Valenzuela R (2012) Bioconversion of alpha-linolenic acid to n-3 LCPUFA and expression of PPAR-alpha, acyl Coenzyme A oxidase 1 and carnitine acyl transferase I are incremented after feeding rats with alpha-linolenic acid-rich oils. Food Funct 3(7):765-772. doi:10.1039/c2fo30012e

Gorres BK, Bomhoff GL, Morris JK, Geiger PC (2011) In vivo stimulation of oestrogen receptor alpha increases insulin-stimulated skeletal muscle glucose uptake. J Physiol 589(Pt 8):2041-2054. doi:10.1113/jphysiol.2010.199018

Hardie DG, Ross FA, Hawley SA (2012) AMPK: a nutrient and energy sensor that maintains energy homeostasis. Nat Rev Mol Cell Biol 13(4):251-262. doi:10.1038/nrm3311

Harris WS, Bulchandani D (2006) Why do omega-3 fatty acids lower serum triglycerides? Curr Opin Lipidol 17(4):387-393. doi:10. 1097/01.mol.0000236363.63840.16

Harris W, von Schacky C, Park Y (2013) Standardizing methods for assessing omega-3 fatty acid biostatus. In: McNamara RK (ed) The Omega-3, Fatty Acid Deficiency Syndrome Nova Science Publishers, Inc. Hauppauge, New York, USA, pp 385-398

Hassan HA, El Wakf AM, El Gharib NE (2013) Role of phytoestrogenic oils in alleviating osteoporosis associated with ovariectomy in rats. Cytotechnology 65(4):609-619. doi:10.1007/ s10616-012-9514-6

Jimenez-Gomez Y, Marin C, Peerez-Martinez P, Hartwich J, Malczewska-Malec M, Golabek I, Kiec-Wilk B, Cruz-Teno C, Rodriguez F, Gomez P et al (2010) A low-fat, high-complex carbohydrate diet supplemented with long-chain (n-3) fatty acids alters the postprandial lipoprotein profile in patients with metabolic syndrome. J Nutr 140(9):1595-1601. doi:10.3945/jn. 109.120816

Kim JY, Jo KJ, Kim OS, Kim BJ, Kang DW, Lee KH, Baik HW, Han MS, Lee SK (2010) Parenteral 17beta-estradiol decreases fasting blood glucose levels in non-obese mice with short-term 
ovariectomy. Life Sci 87(11-12):358-366. doi:10.1016/j.1fs. 2010.07.009

Kinoshita S, Ogawa W, Okamoto Y, Takashima M, Inoue H, Matsuki Y, Watanabe E, Hiramatsu R, Kasuga M (2008) Role of hepatic STAT3 in the regulation of lipid metabolism. Kobe J Med Sci 54(4):200-208

Lu J, Borthwick F, Hassanali Z, Wang Y, Mangat R, Ruth M, Shi D, Jaeschke A, Russell JC, Field CJ et al (2011) Chronic dietary n-3 PUFA intervention improves dyslipidaemia and subsequent cardiovascular complications in the JCR:LA- cp rat model of the metabolic syndrome. Br J Nutr 105(11):1572-1582. doi:10. 1017/s0007114510005453

Marks KA, Kitson AP, Stark KD (2013) Hepatic and plasma sex differences in saturated and monounsaturated fatty acids are associated with differences in expression of elongase 6, but not stearoyl-CoA desaturase in Sprague-Dawley rats. Genes Nutr 8(3):317-327. doi:10.1007/s12263-012-0325-3

Mayes JS, Watson GH (2004) Direct effects of sex steroid hormones on adipose tissues and obesity. Obes Rev 5(4):197-216. doi:10. 1111/j.1467-789X.2004.00152.x

Motawi TM, Hashem RM, Rashed LA, El-Razek SM (2009) Comparative study between the effect of the peroxisome proliferator activated receptor-alpha ligands fenofibrate and n-3 polyunsaturated fatty acids on activation of $5^{\prime}$-AMP-activated protein kinase-alpha1 in high-fat fed rats. J Pharm Pharmacol 61(10):1339-1346. doi:10.1211/jpp/61.10.0010

Paquette A, Wang D, Jankowski M, Gutkowska J, Lavoie JM (2008) Effects of ovariectomy on PPAR alpha, SREBP-1c, and SCD-1 gene expression in the rat liver. Menopause 15(6):1169-1175. doi:10.1097/gme.0b013e31817b8159

Pfaffl MW, Lange IG, Daxenberger A, Meyer HH (2001) Tissuespecific expression pattern of estrogen receptors (ER): quantification of ER alpha and ER beta mRNA with real-time RT-PCR. Apmis 109(5):345-355

Ras RT, Demonty I, Zebregs YE, Quadt JF, Olsson J, Trautwein EA (2014) Low doses of eicosapentaenoic acid and docosahexaenoic acid from fish oil dose-dependently decrease serum triglyceride concentrations in the presence of plant sterols in hypercholesterolemic men and women. J Nutr 144(10):1564-1570. doi:10. 3945/jn.114.192229

Sekiya M, Yahagi N, Matsuzaka T, Najima Y, Nakakuki M, Nagai R, Ishibashi S, Osuga J, Yamada N, Shimano H (2003)
Polyunsaturated fatty acids ameliorate hepatic steatosis in obese mice by SREBP-1 suppression. Hepatology 38(6):1529-1539. doi:10.1016/j.hep.2003.09.028

Senkal M, Geier B, Hannemann M, Deska T, Linseisen J, Wolfram G, Adolph M (2007) Supplementation of omega-3 fatty acids in parenteral nutrition beneficially alters phospholipid fatty acid pattern. JPEN 31(1):12-17

Stark KD, Holub BJ (2004) Differential eicosapentaenoic acid elevations and altered cardiovascular disease risk factor responses after supplementation with docosahexaenoic acid in postmenopausal women receiving and not receiving hormone replacement therapy. Am J Clin Nutr 79(5):765-773

Suchankova G, Tekle M, Saha AK, Ruderman NB, Clarke SD, Gettys TW (2005) Dietary polyunsaturated fatty acids enhance hepatic AMP-activated protein kinase activity in rats. Biochem Biophysic Res Commun 326(4):851-858. doi:10.1016/j.bbrc.2004. 11.114

Tiano JP, Delghingaro-Augusto V, Le May C, Liu S, Kaw MK, Khuder SS, Latour MG, Bhatt SA, Korach KS, Najjar SM et al (2011) Estrogen receptor activation reduces lipid synthesis in pancreatic islets and prevents beta cell failure in rodent models of type 2 diabetes. J Clin Investig 121(8):3331-3342. doi:10. $1172 /$ jci44564

Ukropec J, Reseland JE, Gasperikova D, Demcakova E, Madsen L, Berge RK, Rustan AC, Klimes I, Drevon CA, Sebokova E (2003) The hypotriglyceridemic effect of dietary n-3 FA is associated with increased beta-oxidation and reduced leptin expression. Lipids 38(10):1023-1029

Zhang T, Zhao S, Li W, Ma L, Ding M, Li R, Liu Y (2014) High-fat diet from perilla oil induces insulin resistance despite lower serum lipids and increases hepatic fatty acid oxidation in rats. Lipids Health Dis 13:15. doi:10.1186/1476-511x-13-15

Zhu L, Brown WC, Cai Q, Krust A, Chambon P, McGuinness OP, Stafford JM (2013) Estrogen treatment after ovariectomy protects against fatty liver and may improve pathway-selective insulin resistance. Diabetes 62(2):424-434. doi:10.2337/db111718

Zoth N, Weigt C, Laudenbach-Leschowski U, Diel P (2010) Physical activity and estrogen treatment reduce visceral body fat and serum levels of leptin in an additive manner in a diet induced animal model of obesity. J Steroid Biochem Mol Biol 122(1-3):100-105. doi:10.1016/j.jsbmb.2010.03.029 